\title{
Empirical Analysis of the Impact of Foreign Private Investment on Capital Formation in Nigeria
}

\author{
Salisu Baba Manu1, Chindo Sulaiman², Muhammad Bello Ibrahim ${ }^{3}$, Damina Hamid Babawulle ${ }^{4}$ \\ Department of Economics, Faculty of Social and Management Sciences, Bauchi State University Gadau, Nigeria \\ *Correspondence: sbmmisau@gmail.com
}

\begin{abstract}
The study empirically determines and explores the economic impact of foreign private investment on the economic growth and development of Nigeria over the period under study which is between 1980 and 2015. Unit root test was conducted based on $\mathrm{ADF}$ and PP technique, and all the variables were found to be stationary at level. Johansen co integration test was also employed to check the long run relationship among the variables of study, the result reveal the existence of long run equilibrium. Short run relation was also examined using ECM technique, result confirm a short run relation among the variables. OLS method was employed to estimate the parameters of the model. Empirical result from revealed that, Foreign Private Investment (FPI) has a negative and significant effect on capital formation in Nigeria. Therefore we can reliably conclude that foreign private investment impacted negatively on the domestic capital formation in Nigeria within the period under study (1980-2015). We therefore recommend that; government should take good measures to control inflation. Additionally adequate efforts should be made to mobilize desired gross national savings which would be big enough to attract direct foreign private investment. And finally efforts should be made by government to reduce exchange rate distortions and or misalignment, increase export of locally manufactured goods and raw materials in a bid to raise value of the local currency, the naira; earn more foreign exch ange and allow market forces to properly fix the exchange rate.
\end{abstract}

Keywords: FPI, Capital formation, OLS, Co integration

\section{Introduction}

The issue of foreign private and foreign direct investment and economic growth has been a topic of interest and discussion among scholars and researchers. In the late 1970s and early 1980s, most developing countries of Africa including Nigeria experienced unprecedented and severe economic crises. These crises manifested itself in several ways such as persistent macroeconomic imbalances, widening savingsinvestment gap, high rates of domestic inflation, chronic balance of payment problems and huge budget deficits. (Akpokodje1998). [1] Greene and Villannueve (1991) [2] attributed the problem to the decline in investment rates in the affected economies. In Nigeria for example, Akpokodje (1998) ${ }^{[1]}$ maintained that domestic investment as a ratio of gross domestic product (GDP) declined from an average of $24.4 \%$ during the $1973-1981$ period to $13.57 \%$ during 1982 1996 period. The average during the 1982-1996 period implied that the country barely replaced its dwindling capital. In the same vein, private investment rate depreciated from $8.65 \%$ in $1973-1981$ to $4.2 \%$ in 1982 to 1986 era. Due to the fact that investment determines the rate of accumulation of physical capital (otherwise called capital formation), it then become a vital factor in the growth of productive capacity of the nation and contributes to growth generally. It is in the light of this that prominence is being attached to increase the magnitude of real asset investment in the economy. In particular, central to the less than satisfactory growth registered by countries of sub-Saharan Africa is due to low investment as a result of low domestic savings. Attracting foreign investment is therefore crucial from a number of standpoints and of course, there is never a shortage of theoretical arguments (Chete1998) [3]. First, consistent and regulated inflow of foreign investment provides an important source of foreign exchange earnings needed to supplement domestic savings and raise investment levels. Second, import substituting investment would serve to reduce import bills as investment in export industries would directly increase the country's foreign exchange earnings.

Some other benefits might also accrue from increased foreign investment. These include the creation or rather expansion of local industries to supply inputs to the newly established plants, a rise in the overall level of domestic demand to boost incomes, through taxation, state revenues, and the transfer of labor (human capital) skill and technology. Yet another sets of benefit arises from the forecasting of efficiency in the domestic economy, an effect that might even occur prior to 
the anticipated income flows (Chete, 1998) ${ }^{[3]}$. Most probably due to this overwhelmingly attractive arguments in support of foreign investment, government authorities in Nigeria have often articulated a plethora of incentive aimed at attracting foreign investment. For example the New Industrial Policy published in 1988 embodies some Foreign Direct Investment (FDI) provisions which represent a dramatic departure from the past policy (Chete, 1998) [3].

Besides, the need for external capital inflow arises, when desired investment exceeds actual savings, they are necessary also owing to investments with long gestation periods that generate non-monetary returns, growing government expenditures that are not tax financed and when actual savings are lower than potential savings repress financial markets (Ogamba, 2003) ${ }^{[4]}$.

Many developing countries have over the years relied very much on the inflow of financial resources from outside in various forms; official and private capital flows as well as direct foreign investment as a means of speeding up their economic development (Olaniyi, 1988 ${ }^{[7]}$; Odozi, 1995 $5^{[8]}$; Ekpo, 1997[9] and Uremadu, 2006 $\left.{ }^{[10]}\right)$. However, these countries have shown preferences for direct foreign investment because they regard it as a means of concentrating the sluggish trend in official and private portfolio capital flows.

Generally capital flow from outside can be very helpful in speeding up the pace of economic development and can act as a catalyst agent in making it possible to harness domestic resources particularly in a developing country. But foreign capital cannot absolve a recipient country from the task of mobilizing domestic resources. Foreign inflows can at best be complementary to domestic savings. In developing economies experience has shown that foreign capital alone cannot create any permanent basis for a higher standard of living. Rather, it complements domestic savings. Therefore, the greater dependence on internal sources of finance facility, the more successful the implementation of any planned economic development in a country (Agu, 1988 ${ }^{[11]}$ \& Uremadu, 2006 ${ }^{[10]}$ ). But after over two decades of economic adjustment, all relevant indicators have suggested that the recovery of private investment in Nigeria has been sluggish and slow. For example the cumulative foreign private investment as a percentage of GDP has been fluctuating over the years 1980-2015. It has followed a downward trend from the position of $7.12 \%$ in 1980 to a peak of $12.79 \%$ in 1986 and to its status of $2.7 \%$ in 2015. The same trend has been exhibited by the Gross Domestic Investment also known as Goss Fixed Capital Formation (GFCF). Certainly, macroeconomic, monetary, fiscal policies and exchange rate, have a bearing on the investment behavior in a country (Hadjimichael, Ghuma, Muhleisen, Nord, and Ucer, $1996^{[12]}$; UNCTAD, $2004^{[13]}$ and Akpokodje 1998 ${ }^{[1]}$,), but the impact of these policies on private investment behavior in Nigeria is still largely unclear. In the words of Obadan, (1994) [14]
Nigeria being one of the top three countries that consistently received FDI in the recent decade is not exempted from this group. The Nigerian government is putting too much effort in attracting foreign investors and yet the economy is still dwindling.

Therefore the main objective of this study is to empirically determine and explore the economic impact of foreign private investment on the economic growth and development of Nigeria over the period under study which is between 1980 and 2015.

\section{Literature review}

There are plethora of literatures on the issue of foreign direct and foreign private investment and growth as there were many scholars with much interest on the topic. In this section we are going to segregate the literatures in to theoretical and empirical literatures. One cannot talk about capital formation without at the same time talk about some growth theories available such as Solow growth model, Harrod-Domar growth model and many more.

Elsewhere, Olaniyi (1988) ${ }^{[7]}$ investigates the impact of private foreign capital on domestic investment to ascertain its overall contribution to the enhancement of the domestic savings capacity in Nigeria. His model of domestic savings and investment financing in Nigeria empirically tested the impact of FPI on the level of domestic savings and investment. His results conclude that domestic savings is by far more relevant in determining investment growth than foreign capital inflows in Nigeria. At best, the latter complements the former.

Borensztein, De Gregoria and Lee (1998) ${ }^{[43]}$ see FPI as an important vehicle for the transfer of technology, contributing to growth in larger measure than domestic investment.

Findlay (1978) ${ }^{[44]}$ postulates that FPI increases the rate of technical progress in the host country through a "contagion" effect from the more advanced technology, management practices, etc., used by foreign firms. On the basis of these assertions governments have often provided special incentives to foreign firms to set up companies in their countries. Levine (2005) ${ }^{[37]}$ note that the economic rationale for offering special incentives to attract FPI frequently derives from the belief that foreign investment produces externalities in the form of technology transfers and spillovers.

Blomstrom, and Kokko (1998) ${ }^{[45]}$ report that FPI exerts a positive effect on economic growth, but that there seems to be a threshold level of income above which FPI has positive effect on economic growth and below which it does not. The explanation was that only those countries that have reached a certain income level can absorb new technologies and benefit from technology diffusion, and thus reap the extra advantages that FPI can offer. He also suggests human capital as one of the reasons for the 
differential response to FPI at different levels of income. This is because it takes a well-educated population to understand and spread the benefits of new innovations to the whole economy.

Borensztein et al. (1998) ${ }^{[43]}$ also found that the interaction of FPI and human capital had important effect on economic growth, and suggest that the differences in the technological absorptive ability may explain the variation in growth effects of FPI across countries. They suggest further that countries may need a minimum threshold stock of human capital in order to experience positive effects of FPI.

Balasubramanyan, et al (1996) ${ }^{[48]}$ report positive interaction between human capital and FPI. They had earlier found significant results supporting the assumption that FPI is more important for economic growth in export-promoting than import-substituting countries. This implies that the impact of FPI varies across countries and that trade policy can affect the role of FPI in economic growth.

Bengos and Sanchez-Robles (2003) [47] assert that even though FPI is positively correlated with economic growth, host countries require minimum human capital, economic stability and liberalized markets in order to benefit from longterm FPI inflows.

Interestingly, Bende-Nabende and Ford (1998) ${ }^{[42]}$ found that direct long-term impact of FPI on output is significant and positive for comparatively economically less advanced Philippines and Thailand, but negative in the more economically advanced Japan and Taiwan. Hence, the level of economic development may not be the main enabling factor in FPI growth nexus. On the other hand, the endogenous school of thought opines that FPI also influences long-run variables such as research and development (R\&D) and human capital (Lucas, 1990) ${ }^{[48] .}$

FPI could be beneficial in the short term but not in the long term. Dees (2004) ${ }^{[49]}$, for example, failed to establish a positive relationship between FPI and growth, but instead suggests that the effects of FPI are contingent on the "absorptive capability" of host countries. Obwona (2001) ${ }^{[50]}$ notes in his study of the determinants of FPI and their impact on growth in Uganda that macroeconomic and political stability and policy consistency are important parameters determining the flow of FPI into Uganda and that FPI affects growth positively but insignificantly.

Ariyo (1998) ${ }^{[55]}$ studied the investment trend and its impact on Nigeria's economic growth over the years. He found that only private domestic investment consistently contributed to raising GDP growth rates during the period considered (1970-1995). Furthermore, there is no reliable evidence that all the investment variables included in his analysis have any perceptible influence on economic growth. He therefore suggests the need for an institutional rearrangement that recognizes and protects the interest of major partners in the development of the economy.
Examining the contributions of foreign capital to the prosperity or poverty of LDCs, Ariyo (1998) [55] conceptualized foreign capital to include foreign loans, direct foreign investments and export earnings. Using CheneryStout's two-gap model (Chenery\& Stout, 1966) ${ }^{[54]}$, he concluded that FPI has a negative effect on economic development in Nigeria.

Anyanwu (1998) [56] identified change in domestic investment, change in domestic output or market size, indigenization policy, and change in openness of the economy as major determinants of FPI. He further noted that the abrogation of the indigenization policy in 1995 encouraged FPI inflow into Nigeria and that effort must be made to raise the nation's economic growth so as to be able to attract more FPI.

Adelegan (2000) [57] explored the seemingly unrelated regression model to examine the impact of FPI on economic growth in Nigeria and found out that FPI is pro-consumption and pro-import and negatively related to gross domestic investment. Akinola[63] (2004) found that foreign capital has a small and not statistically significant effect on economic growth in Nigeria.

\section{Methodology}

This study employed secondary annual time series data. Time series data is advantageous because it captures a country's specific behaviors and devoid of endogeneity, thus providing an in depth policy implication (Forbes, 2000). The data on all the variables employed in this study were sourced from World Bank data base covering the period of 1980-2015; this is largely due to the availability of data on all the variables however the sample period is adequately enough for time series data as many scholars consider thirty or more samples or observations are enough for a good time series analysis. With respect to the statistical tool of analysis the study employed Augmented Dickey Fuller (ADF) and Philips Peron method of stationary testing. These methods were employed in order to check the stationarity of the time series data employed in this study. The study also employed co integration test based on johanssen co integration technique in order to test for the existence of long run relationship between or among the dependent and other explanatory variables used in the study. The study also employed or adopted the use of famous Ordinary Least Square method in order to estimate the parameters of a model. Multiple linear regressions was used to estimate the variables or parameters of the model. See S.B. Manu and Chindo S. (2018). Other diagnostic tests such as D.W test for autocorrelation, normality test, CUSUM and CUSUM sum of squares were all employed to check for the fitness of the model.

\section{Model Specification}

$\mathrm{GFCF}=\partial 0+\partial 1 \mathrm{FPI}+\partial 2 \mathrm{GNS}+\partial 3 \mathrm{INF}+\partial 4 \mathrm{INT}+\partial 5 \mathrm{EXR}$ $+\mu \ldots$ (1)

$\Delta \mathrm{GFCF}=\partial 0+\partial 1 \Delta \mathrm{FPI}_{\mathrm{t}-\mathrm{i}}+\partial 2 \Delta \mathrm{GNS}_{\mathrm{t}-\mathrm{i}}+\partial 3 \Delta \mathrm{INF}_{\mathrm{t}-\mathrm{i}}+\partial 4$ $\Delta \mathrm{INT}_{\mathrm{t}-\mathrm{i}}$ 
$+\partial 5 \Delta \mathrm{EXR}_{\mathrm{t}-\mathrm{i}}+\mu \ldots$. (2) Where:

GCFC $=$ Gross Fixed Capital Formation

FPI= Foreign Private Investment

GNS $=$ Gross National Savings

$\mathrm{INF}=$ Domestic Inflation Rate

INT $=$ Interest Rate on Lending

$\mathrm{EXR}=$ Foreign Exchange Rate

Findings and discussion
Table 2, above presents or shows the co-integration tests result of the model. The co integration results revealed the existence of a unique co-integrating vector for both maximum eigenvalue test and trace test. It can be seen that there is evidence of long run relationship between the dependent and other independent variables, this is evident by the presence of two co integration equations in the $\mathrm{JJ}$ test.

Table 3, above presents the result or estimates of the multiple

Table 1: Unit root test results

\begin{tabular}{|c|c|c|c|c|}
\hline \multirow[t]{2}{*}{ Variables } & \multicolumn{2}{|l|}{ Constant } & \multicolumn{2}{|c|}{ Constant and trend } \\
\hline & ADF & PP & ADF & PP \\
\hline GFCF & $\begin{array}{l}-10.695 * * * \\
(0.000)\end{array}$ & $\begin{array}{l}-7.999 * * * \\
(0.000)\end{array}$ & $\begin{array}{l}-10.850 * * * \\
(0.000)\end{array}$ & $\begin{array}{l}-10.953^{* * * *} \\
(0.000)\end{array}$ \\
\hline FPI & $\begin{array}{l}-4.675 * * * \\
(0.000)\end{array}$ & $\begin{array}{l}-4.274184 * * \\
(0.002)\end{array}$ & $\begin{array}{l}-5.256 * * * \\
(0.000)\end{array}$ & $\begin{array}{l}-6.841 * * * \\
(0.000)\end{array}$ \\
\hline GNS & $\begin{array}{l}-8.089 * * * \\
(0.000)\end{array}$ & $\begin{array}{l}-18.90332 * * * \\
(0.000)\end{array}$ & $\begin{array}{l}-7.958 * * * \\
(0.000)\end{array}$ & $\begin{array}{l}-19.624 * * * \\
(0.000)\end{array}$ \\
\hline INF & $\begin{array}{l}-6.885^{* * * *} \\
(0.000)\end{array}$ & $\begin{array}{l}-24.980 * * * \\
(0.000)\end{array}$ & $\begin{array}{l}-6.829 * * * \\
(0.000)\end{array}$ & $\begin{array}{l}-31.127 * * * \\
(0.000)\end{array}$ \\
\hline INT & $\begin{array}{l}-7.016 * * * \\
(0.000)\end{array}$ & $\begin{array}{l}-29.767 * * * \\
(0.000)\end{array}$ & $\begin{array}{l}6.916 * * * \\
(0.000)\end{array}$ & $\begin{array}{l}-32.217 * * * \\
(0.000)\end{array}$ \\
\hline EXCR & $\begin{array}{l}-5.163 * * * \\
(0.000)\end{array}$ & $\begin{array}{l}-5.161 * * * \\
(0.000)\end{array}$ & $\begin{array}{l}-5.204 * * \\
(0.001)\end{array}$ & $\begin{array}{l}-5.204 * * \\
(0.001)\end{array}$ \\
\hline
\end{tabular}

Note $* * *, * *, *$ denotes significance at $1 \%, 5 \%$ and $10 \%$ respectively.

Table 2: Johansen-Juselius (JJ) Co integration Test Results

\begin{tabular}{lllll}
\hline Null Hypothesis & Test Statistics & \multicolumn{3}{l}{ Critical values (5\%) } \\
\cline { 2 - 5 } & Trace & Max-Eigen & Trace & Max-Eigen \\
\hline None* & 167.524 & 69.418 & 95.753 & 40.077 \\
At most 1* & 98.105 & 40.696 & 69.818 & 33.876 \\
At most 2* & 57.409 & 33.054 & 47.856 & 27.584 \\
\hline
\end{tabular}

Table 3: Ordinary least square (OLS) multiple regression result

\begin{tabular}{lllllll}
\hline Estimate & Constant & FPI & GNS & INF & INT & EXCR \\
\hline JJ & -48.881 & $-3.510 * * *$ & -0.475 & $-1.777^{* * *}$ & $-3.787^{* * * *}$ & $-0.256^{* * *}$ \\
& & $(6.127)$ & $(-1.252)$ & $(11.428)$ & $(12.173)$ & $(7.148)$ \\
\hline
\end{tabular}

Note numbers in bracket are t-statistics.

Note $* * *, * *, *$ denotes significance at $1 \%, 5 \%$ and $10 \%$ respectively

Table 1 above presents the results of a unit root or stationarity test of the time series data. The result revealed or shows that all the variables were found to be stationary at level. Therefore the null hypothesis of the unit root can be rejected for the giving variables. Given that the variables were stationary at level we have basis for examining their long run equilibrium using co integration and OLS to estimate the parameters in the model. regression. The results indicate that the foreign private investment (FPI) has a negative effect or impact on the domestic capital formation in Nigeria. The relationship is statistically significant and in accordance with the rule of thumb, thus the coefficient is statistically significant. To be specific a unit increase in foreign private investment will decrease gross fixed capital formation growth by 3.510. This implies that FPI crowds out domestic investment in the case of Nigeria. This finding is consistent with the findings of other 
researchers in Nigeria. Adelegan (2000) also reported a negative relationship between foreign private investment and capital formation. This is simply because FPI crowds out domestic investment in the case of Nigeria. In the short run also FPI have a negative and significant impact on capital formation. But the magnitude of the impact is larger in the long run than in the short run. In the short run a unit increase in FPI will reduce GFCF by 0.02 which is also statistically significant. fixed capital formation growth by 1.777 . The negative and significant coefficient of inflation rate, indicate or implied that accelerating inflation is a serious disincentive to raising high capital formation for the national economy. However in the short run inflation has a significant positive impact on capital formation. This is because inflation could lead to higher income and profits in the short run. In the short run a unit increase in inflation will increases gross fixed capital formation by 0.194 .

Also in the long run the coefficient of the level of exchange

Table 4: The Error- Correction Model (ECM)

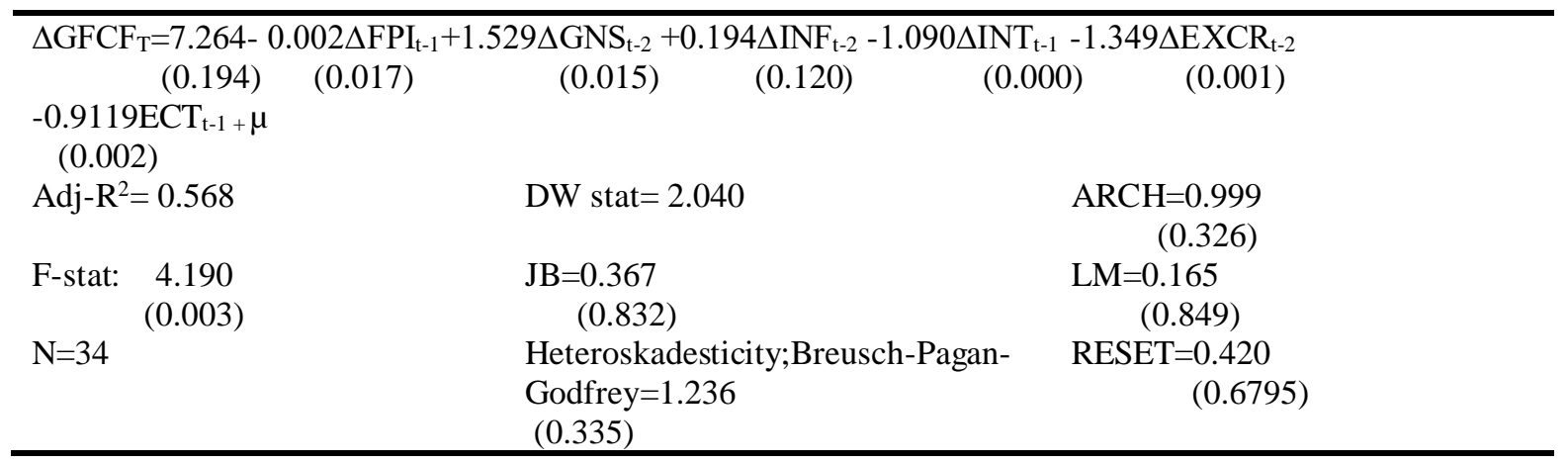

The estimated coefficient of the gross national savings (GNS) shows a negative and insignificant impact on capital formation. A unit increase in gross national savings will decrease gross fixed capital formation growth by 0.475 . The negative effect suggests that; foreign private investment in real terms has crowded out gross domestic savings since the latter is so low and distorted that it cannot positively and significantly impacted on capital formation or gross domestic investment (GDI) as at its present low status profile. Gross national savings (GNS) low rating has not formed a good base to attract more foreign private investments into the country to adequately complement savings in order to raise domestic capital formation. Hence, inadequate foreign private investment results in the size of both gross national savings and foreign private investment as they presently stand in Nigeria cannot make the desired significant impact on capital formation. Nigeria's gross national saving rate does not command good leverage to attract adequate foreign private investments into the national economy. On the contrary, in the short run gross national savings have a positive impact on capital formation and this could be because of time lag. Thus foreign private investment takes time to crowd out gross national savings. In the short run a unit increase in gross national savings will increase gross fixed capital formation by 1.529 .

In the long run capital formation is also sensitive to the domestic inflation rate (INF), the coefficient of inflation rate is was found to be negative and statistically significant. This implies that a unit increase in inflation rate will decrease gross rate (EXCR) on capital formation is negative and statistically significant. A unit increase in exchange rate will decrease gross fixed capital formation by approximately 0.256 . This implies that high exchange rate may have a negative impact on capital formation. The international real exchange rate is inversely related to capital formation. Even in the short run the coefficient of exchange rate exhibits a negative and significant impact on capital formation. A unit increase in exchange rate will decrease gross fixed capital formation growth by 1.349 . The ECT coefficient of $(-0.911)$ which is also statistically significant sustains the long run relationship among the variables and denotes that the speed of adjustment of variables convergence to equilibrium is $91.1 \%$.

The coefficient of determination $\mathrm{R}^{2}$ is 0.75 , an adjusted coefficient of determination $\left(\mathrm{R}^{2}\right)$ of 0.568 were derived. This means that about $57 \%$ of the systematic mean variations of the dependent variable (GFCF) is explained by the explanatory variables (FPI, GNS, INF, INT and EXCR). This means that the estimated regression model line is a good fit, hence the regression result command a moderate predicting value. The F-statistic result (4.190) reveals that the estimated regression model passed the overall significant test (F-test) at an acceptable 5\% level of significance. This is an indication that there is a linear relationship between the dependent variable (GFCF) and the explanatory variables (FPI, GNS, INF, INT and EXCR) hence none of the estimated coefficient is equal to zero.

Other diagnostic tests were conducted in order to check for the fitness and stability of the model. Among the diagnostic 
tests and their results suggest that; The LM test and Durbin Watson (DW) stats shows that there is no presence of serial correlation in the model. The JarqueBera test shows that the data in the model were normally distributed. With respect to the Heteroskedasticity; Breusch-Pagan-Godfrey and ARCH shows no sign of heteroskedasticity in the model.

The RESET test shows that the model has been correctly specified. The results for CUSUM,

CUSUMQ can be presented as figures below.

Figure 1: CUSUM

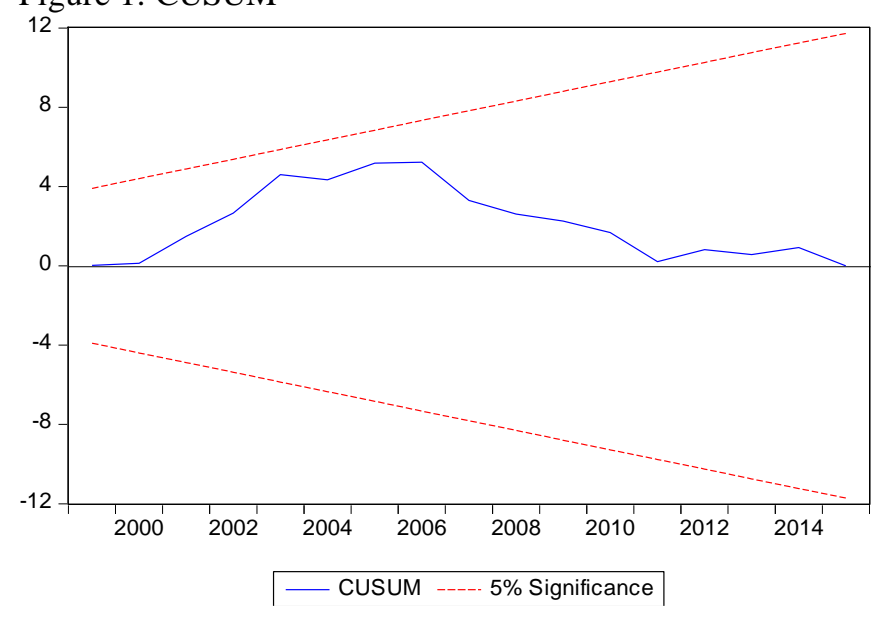

Figure 2: CUSUM SUM OF SQUARES

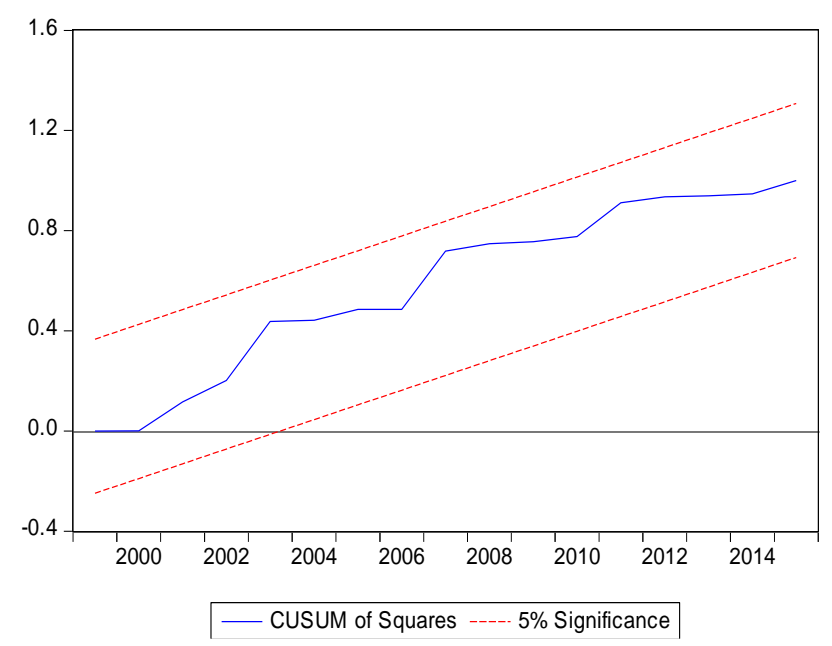

As suggested by Pesaran, Shin, and Smith (2011) [60], a stability test for the model based on CUSUM and CUSUMSQ tests has been conducted. It is suggested that for a model to be stable along the sampled period, the residuals must be within the straight lines of the critical bounds at a $5 \%$ significance level. Figure 1 and 2, depicts the results. All the figures show that the model is reasonably stable over the period of study. The results for CUSUM and CUSUMQ also suggest that the model is stable and a good fit.

\section{Conclusion}

The study empirically examined the impact of foreign private investment on capital formation in Nigeria. The objective is to determine how foreign private investment affects capital formation in the domestic economy. Empirical evidence revealed that, Foreign Private Investment (FPI) has a negative and significant effect on capital formation in Nigeria. Therefore we can reliably conclude that foreign private investment impacted negatively on the domestic capital formation in Nigeria within the period under study (19802015). This is consistent with the outcomes of the number of studies and findings in the empirical literature. That foreign private investment crowds out domestic investment is not surprising because the technology of foreign firms enables them to produce at highly competitive rates thereby driving high cost inefficient domestic firms out of business. For example, MTEL telecommunication firm owned by the Federal government of Nigeria has already gone out of business because it has not been able to measure up to the expectations of mobile telecommunication in the Nigerian market, thus it can't compete with its foreign counterpart such as MTN and AIRTEL in the Telecommunication industry in Nigeria.

In view of the above conclusion we make these recommendations; government should take good measures in order to maintain a steady and healthy level of inflation rate. The economy cannot raise gross domestic investment (i.e. capital formation) and national productivity level without maintaining adequate low level of inflation rate necessary for growth. Additionally adequate efforts should be made to mobilize desired gross national savings which would be big enough to attract direct foreign private investment that will complement domestic savings towards raising capital formation to a level needed for the desired industrial growth and development. And finally efforts should be geared by government to reduce exchange rate distortions and or misalignment, increase export of locally manufactured goods and raw materials in a bid to raise value of the local currency, the naira; earn more foreign exchange and allow market forces to properly fix the exchange rate. This policy thrust will most likely result into increased capital formation in Nigeria needed for the real sector investments and industrial growth in Nigeria.

\section{REFERENCES}

[1]. Akpokodje, G. (1998), "Macroeconomic Policies and Private Investment inNigeria" In Rekindling Investment for Economic Development inNigeria by Ben E. Aigbokhan(ed). Selected papers for the 
1998Annual Conference, the Nigerian Economic Society.

[2]. Green, J \&Villannueva, D (1991), "Private Investment in Developing Countries: An Empirical Analysis. IMF Staff Papers 38(2): 33 58

[3]. Chete, L.M. (1998), "Determinants of Foreign Direct Investment inNigeria." SER MonoraphSeries. 7:289-336.

[4]. Ogamba, E.N (2003) "The Impact of Globalization on Foreign Capital Flows in Nigeria" An unpublished ph. D thesis submitted to the Department of Banking and Finance, UNN, Enugu Campus.

[5]. Adegbite, E.O. \&Owuallah, S.I. (2007), “1st National Finance andBanking Conference on Economic reforms and The NigerianFinancial System". A communique read at National Conferenceorganized by the Department of Finance, University of Lagos,Nigeria, 3 -4 April, 2007.

[6]. Fedestien C. (2000), "Domestic Savings and International capital flows" .Economic Journal, 90: 314 -329.

[7]. Olaniyi, O. (1988), “An Econometric Analysis of Domestic Savings and Investment Financing in Nigeria". Journal of Teacher Education.4 (1):133 $-132$.

[8]. Odozi, V.A. (1995), an Overview of Foreign Investment in Nigeria 1960-1995. Occasional Paper No. 11. Research Department, Central Bank of Nigeria.

[9]. Ekpo, A.H (1997), "Foreign Direct Investment in Nigeria: Evidence from Time Series Data". CBN Economic and Financial Review, 35 (1)

[10]. Uremadu, S.O (2006), "The Impact of Real Interest Rate on Savings Mobilization in Nigeria". An unpublished $\mathrm{Ph}$. D thesis submitted to the Department of Banking and Finance, UNN Enugu, Campus.

[11]. Agu, C.C. (1988), Nigerian Banking Structure and Performance: TheBanking Systems Contribution to Economic Development. Onitsha:African -FEP Publishers.

[12]. Hadjimichael,D.Ghuma, M., Muhleisen M., Nord, R. \&Ucer E. (1995), "Growth, Savings and Investment". New York: International Monetary Fund.

[13]. UNCTAD. (2004). World Investment Report. Geneva: United Nations Conference on Trade and Development. World Bank. (1998, 1999, 2004). World Development Indicators.
[14]. Obadan, M.I, (1994), "Direct Investment in Nigeria: An empirical Analysis "African Studies Review 25(1): 67-81.

[15]. Smith, (2003), Economic Development: Eight Edition Pearson Education Inc. $634-666$. Solow, R. 1956. "A Contribution to the theory of economic growth". Quarterly Journal of Economics, 70: 65-94.

[16]. Hakkio, C.S (2000), "The U.S Current Account The Other Deficit". Economic Review, Federal Reserve Bank of Kansas.

[17]. Schmuckler, S.I (2003), "Financial Globalization: Gain and Pain for Developing Countries". World Bank Policy Research Report.

[18]. Galenson, J. \&LeibenstenB. (1995), "Financial Liberalization, FinancialDevelopment and Economics development". Quarterly Journal of Economics, 108: $717-73$

[19]. Harrod, Roy F. (1939). "An Essay in Dynamic Theory". The Economic Journal. 49 (193): 14-33.

[20]. Domar, E (1946). "Capital Expansion, Rate of Growth, and Employment". Econometrica. 14 (2): 137-147.

[21]. Miller, G.N., \&D.N. Baldwin. (1992), “A contribution to the empirics of growth". Quarterly Journal of Economics, 107: 407-37.

[22]. Lewis, A. W (1978), Economic Development and Unlimited Supplies of Labour. Manchester School Press.

[23]. Robert, C. Fenstra \& Hanson, H. G (2001), Global Production Sharing and Rising Inequality: A Survey of Trade and Wages. Natioanal Breau of Economic Research. 1050 Massachusetts Avenue.

[24]. Dunning, J.H (1981), "Explaining the International Direct InvestmentPosition of Countries: Towards a Dynamic or DevelopmentalApproach.” www.wiltwirt schaftlickes arch. 117: 30-64.

[25]. Caves, R.E. 1996. Multinational Enterprise and Economic Analysis. 2nd ed.Cambridge:Cambridge University Press. Central Bank of Nigeria (various years): Central Bank of Nigeria StatisticalBulletin. Abuja, Nigeria.

[26]. Aremu, J.A. (1997), "Foreign Private Investment: Issues, Determinants, Performance andPromotion" CBN research papers, No.4, (July, 1997).

[27]. Mishara, M.I\& J. Mody (2004), "Foreign Capital Flows and External Debt: Perspectives on Nigeria and the LDCS Group". Lagos: Broadway Press Limited.

[28]. De Mello, L. R. (1954), "Foreign Direct Investment in developing countriesand growth: A 
selective survey". Journal of Development Studies, 34(1):1-34.

[29]. Agarwal, J.P (1980), "Determinants of Foreign Private Investment: ASurvey" welliirtschagtlichesAchive, 117:30-64

[30]. French, K \&Poterba, J (1991) "Investor diversification and International equity markets". American Economic Review 81:222 -226.

[31]. Obstified M. \&Rogoff, K (2000), "The six Major puzzles in international Macroeconomics: Is there a common cause? NBER working paper7777:743750 .

[32]. Fisher, S (1995), "The Role of Macroeconomic factors in Growth". Journal of Monetary Economics, 32: 458 -512.

[33]. Chalapti R.K.S. (1999), "Foreign Institutional Investments and the IndianStock Markets", Journal of Indian School of Political Economy.11 (4): $623-627$

[34]. Lim. E. (2001), "Determinants of and relationship between foreign direct investment and growth: A summary of recent literature". IMFWorking Paper No. 175.Washington, D.C.

[35]. Cobham, A. (2001), "Capital account liberalisation and impact on the poor". Paper produced for Oxfam and Bretton Woods project.

[36]. Edozien, E. E. (1968), "Linkages: Direct Foreign Investment and Nigeria'sEconomic Development." Nigerian Journal of Economic and Social Studies 10 (2): $191-203$.

[37]. Levine R. (2005), "Financial Intermediation and growth: Theory and Evidence" in the Handbook of Economic Growth in Netherlands: Elsevier Science press.

[38]. Olakampo, O. (1962), "Foreign Aid and the Plan". Nigerian Journal of Economic and Social Studies. 492:116 - 125

[39]. Oyaide, W. J (1977), The Role of Direct Private Foreign Investment in Economic Development: A case study of Nigeria 1962 -1973.Washington D.C: United Press of America.

[40]. Olopoenia, R. A (1983), "Foreign Investment and Growth Rates of Capital Importing Countries: A Technical Note". Nigerian Journal of Economic and Social Studies. 25(2): 221 -32.

[41]. Oseghale, B.D. \& E.E. Amonkhienan. (1987), "Foreign debt, oil export,direct foreign investment (1960-1984)". The Nigerian Journal of Economic and Social Studies, 29(3): 359-80.

[42]. Bende-Nabende, A. \&J.L Ford. (1998), "FDI, policy adjustment andendogenous growth:Multiplier effects from a small dynamic modelfor Taiwan 1959-1995". World Development 26(7): 1315-30.
[43]. Borensztein, E., J. De Gregoria\&J. Lee. (1998), "How does foreign investment affect economic growth?" Journal of International Economics, 45(1): 115-135.

[44]. Findlay, R. (1978), "Relative backwardness, direct foreign investment andthe transfer of technology: A simple dynamic model". QuarterlyJournal of Economics, 92: 1-16.

[45]. Blomstrom, M. \&A. Kokko. (1998), "Multinational corporations andspillovers". Journal of Economic Survey, 12(3): 247-77.

[46]. Balasubramanyan, V., N. Mohammed, A. Salisu\&David Sapsford. (1996), "Foreign direct investment and growth in EP and IS countries",Economic Journal, 106: 92-105.

[47]. Bengos, M. \&B. Sanchez-Robles. (2003), "Foreign Private Investment, economic freedom and growth: New evidence from Latin America". European Journal of Political Economy, 19(3): 529-45.

[48]. Lucas, R.E (1990), "Why doesn't capital flow from rich to poor countries?" The American Economic Review: 80(2): 92 -96.

[49]. Dees, S. (2004), "Foreign private investment in China: Determinants andeffects". Economics of Planning, 31: 175-94.

[50]. Obwona, Marios B. (2004), "Foreign direct investment in Africa". In Financing Pro-Poor Growth: AERC Senior Policy Seminar VI, Kampala, Uganda, 2-4 March 2004 - Seminar Papers, pp. 60-95.Nairobi: African Economic Research Consortium.

[51]. Markussen, J.R. \&A.J. Vernable. (1998), "Multinational firms and the new trade theory". Journal of International Economics, 46: 183-203.

[52]. Ogiogio, G.O. (1995), "Planning horizon, government expenditure and economic growth in Nigeria”. In A. Ariyo, ed., Economic Reform Macroeconomic Management in Nigeria. Ibadan: The Centre for Public-Private Cooperation.

[53]. Aluko, S.A. (1961), "Financing economic development in Nigeria". TheNigerian Journal of Economic and Social Studies, 3(1): 39-67.

[54]. Chenery, H. B. \&A. Stout 1966. "Foreign Assistance and EconomicDevelopment". American Economic Review Vol. 55 pp.679-733.

[55]. Ariyo, A. (1999), "Investment and Nigeria's economic growth". AnInvestment in theGrowthProcess Proceedings of Nigerian EconomicSociety Annual Conference 1998:389415.Ibadan, Nigeria.

[56]. Anyanwu, J.C. 1998. “An econometric investigation of determinants offoreign direct investment in Nigeria". In Investment in the 
GrowthProcess: Proceedings of the Nigerian Economic Society Conference1998:219-240. Ibadan, Nigeria.

[57]. Adelegan, J.O. (2000), "Foreign direct investment and economic growth inNigeria:A seemingly unrelated model". African Review of Money,Finance and Banking, Supplementary issue of "Savings andDevelopment" 2000:.5-25. Milan, Italy.

[58]. Akinola, A.E. (2004), "Foreign direct investment and growth in Nigeria: Anempiricalinvestigation". Journal of Policy Modelling, 26: 627-639.

[59]. Mckinnon, R. I. (1973), Money and Banking in Economic Development Washington D.C an Empirical Examination": The Brookings Institute

[60]. Pesaran, M. H., Shin, Y. and Smith, R. P. (2001). Bounds testing approaches to the analysis of level relationships.Journal of Applied Econometrics, $16,289-326$. 